\title{
I Was Once an Oppressor, But I Found the Strength Within to Free Myself
}

\author{
Kevin Cataldo \\ Montclair State University
}

\begin{abstract}
Introduction
Imagine attending public schools your entire life and not once having the opportunity to talk about race and racism in America or the world. Years later, you find yourself completing a teacher education program and feeling ready to influence the hearts and minds of culturally, racially, ethnically, and linguistically diverse students. However, shortly after your first year of teaching in an urban school district, you realize that your teacher education program failed you. You are uncomfortable and inadequately prepared to facilitate critical conversations about race and racism and what it means to be a historically marginalized individual of Color ${ }^{1}$ in your classroom in the United States. This happened to me. During my first year of teaching, I, an educated gay Latino urban educator, had to accept the fact that, rather than being an educator, I was just another oppressor. I chose to uphold the dominant belief that the purpose of schooling in urban America was to teach a Eurocentric curriculum and not to engage in critical conversations about the impact of politics, religion, culture, race, and racism on our lives.
\end{abstract}

In this short reflective essay, I share how I underwent a metamorphosis during the COVID-19 pandemic. For the first time in my life, I chose to use my education and my life experiences as a historically marginalized individual of Color to decolonize my pedagogy. Thanks to the scholarship of Ladson-Billings (1995) and Freire (1996), I was able to transform my pedagogy into one where the cultural and racial identities and lived experiences of my students are acknowledged and validated in our classroom, one where my students-even just for a short period-can experience what it feels like to not be bound by the shackles of society's oppressors.

\section{My First Year Teaching in Urban America: I Am an Oppressor!}

During my first year of teaching, I found myself staunchly upholding the following belief: As a historically marginalized individual of Color, I cannot be an oppressor. But I was wrong; in my very own classroom, I was an oppressor. For instance, during the first two weeks of school, I did not take the time to get to know my students-their interests, cultures, identities, and lived experiences. Thus, instead of being their teacher, I was another oppressor in their lives. While preparing my lesson plans, I approached my curriculum from a Eurocentric and colorblind perspective because I believed that my job as a first year nontenured teacher was to show my school and district leaders that I was a data- and standards-driven professional. The reality is that being an educator in urban America, especially as an individual of Color, means allowing those with power (the oppressors) to recruit and mold you into a compliant puppet-another oppressor.

\footnotetext{
1 "Color" is intentionally capitalized to reject the standard grammatical norm. Capitalization is used as a means to empower this marginalized group of students.
} 
In urban America, oppressors see students and their cultures, identities, and lived experiences as test scores and opportunities for federal funding rather than as human beings. While my students never verbally identified me as an oppressor, I vividly recall not genuinely acknowledging their cultures and lived experiences in the classroom. Today, as I reflect on my first year in the classroom, I recognize that to my students' eyes, I was simply another oppressor towering over them. As such, I was responsible for shutting down their minds and making them compliant and fearful of freedom. In the words of Freire (1996), "The oppressed, having internalized the image of the oppressor and adopted his guidelines, are fearful of freedom" (p. 21). In other words, in urban America today, historically marginalized students of Color cannot find the strength to fight back against an oppressive society and education system, and this allows oppression to continue to thrive in all areas of our society.

Moreover, for those unfamiliar with Freire (1921-1997), he was one of the most influential educational theorists of the 20th century. Throughout his life, Freire fought to provide people with access to a meaningful education that would empower them to grow as learners in an oppressed world. Freire's writings are centered on social, political, and economic inequalities, along with race and social justice. Today, Freire's most notable and seminal text, Pedagogy of the Oppressed (1996), invites us to recognize that we live in an oppressed world where the purpose of education revolves around obedience and transmission of information from teacher to student. The teacher is viewed as the only individual with knowledge, and the role of a student is to be obedient and simply take in the knowledge presented. However, in his book, Freire argues that the purpose of education should be to liberate one's mind. Liberation through education allows students to critically examine power structures and inequalities, which empowers students to become active thinkers and citizens in disrupting the status quo. When students are challenged as learners and empowered to rebel against systemic oppression, they get the opportunity to enhance their critical consciousness. Students and their minds are no longer confined nor required to remain obedient and accept the status quo.

In the next section of this essay, I describe how the COVID-19 pandemic gave me the strength to remove the "internalized image of an oppressor" (Freire, 1996, p. 21) from my mind and the minds of my students. In doing so, I was able to obtain freedom, not only for myself but also for my students.

\section{The COVID-19 Pandemic-Liberation at Last!}

COVID-19 has ended the lives of millions of people. However, over the years, I have learned that there is a blessing in disguise in every tragedy, or at least one profound lesson that prods us to evolve and become better versions of ourselves. Being a novice educator during the pandemic took a toll on both my physical and mental health. Yet, it also provided me with the chance to view teaching from a different perspective- transform my classroom from an oppressed society to a culturally responsive learning environment. I learned that I could not allow standardized testing and a Eurocentric curriculum to negatively impact my pedagogy. In fact, Ladson-Billings' (1995) seminal article "But That's Good Teaching! The Case for Culturally Relevant Pedagogy" provided me with the pedagogical knowledge and strength I required to become the teacher that my students needed. Using the three tenets of culturally relevant pedagogy (which include academic success, cultural competence, and sociopolitical consciousness), I built positive and meaningful relationships with my students for the first time in my teaching career. This was a significant turning point in my career, as I was becoming a culturally responsive 
teacher. For instance, during our unit of study on Christopher Columbus and the Columbian Exchange, through class discussions, my students and I challenged each other's beliefs, and most importantly, concluded that Christopher Columbus impacted our world in both positive and negative ways. During the unit, my students freely shared their thoughts about race and racism in America. At the end of the unit, I was proud of my ability to apply theory into practice. I felt free at last!

Using the theory of culturally relevant pedagogy, I decolonized my pedagogy and facilitated meaningful and genuine conversations about the social, political, and economic injustices that plague our world. Through class discussions, I enabled my students to realize that their voices and lived experiences matter. Deep within me, for the first time in my classroom, I no longer felt like an oppressor; I felt like an imperfect human being, a lifelong learner, and an educator. Thanks to that experience, today I see myself as a teacher who inspires his students to chase after their dreams. Today I make it my primary duty to constantly remind my students that they have the inner strength to make their voices heard, regardless of how uncomfortable they make society, particularly its oppressors feel.

\section{Post-COVID-19-A Hopeful Future}

The COVID-19 pandemic confined students and educators to the four walls of their homes. While I was physically confined, mentally, and emotionally, I was able to envision my classroom as a space where feelings of oppression are nonexistent and where dreams become realities for myself and my students. An important lesson that I learned during the pandemic is that the world needs teachers who seek to free themselves and their students from all types of oppression. As I prepare to begin my third year of teaching, I remind myself of the following important facts: I was once a historically marginalized student of Color in my home city, but today, I am a threat to my oppressors. I am a proud, historically marginalized, gay Latino urban educator of Color. My voice is loud, and my commitment to social justice is just getting started. Our war is far from over.

Kevin Cataldo is a proud Brazilian-American and an urban educator in Newark, New Jersey. He is currently pursuing a Ph.D. in Teacher Education and Teacher Development at Montclair State University. His research interests are qualitative research (self-study research), culturally relevant pedagogy in K-12 urban education, and teacher education.

\section{References}

Freire, P. (1996). Pedagogy of the oppressed. Penguin.

Ladson-Billings, G. (1995). But that's just good teaching! The case for culturally relevant pedagogy. Theory into Practice, 34(3), 159-165. 